\title{
ART AS OTHER COLLECTIVES
}

By Heather Davis (Concordia University)

Art and nature, art in nature, share a common structure: that of excessive and useless production - production for its own sake, production for the sake of profusion and differentiation. (Grosz 2008: 9)

In 1986, artist Lily Yeh was asked by her friend, acclaimed dancer Arthur Hall, to transform the abandoned lot next to his house. He had seen the indoor gardens that she had created in galleries, and asked if she could do a similar project outdoors. When Yeh first entered the North Philadelphia neighbourhood of Fairhill-Hartranft, it was nothing like the neighbourhood she would leave in 2004. Walking down the streets for the first time she saw many adults with suspicious faces staring at her as she made her way past abandoned lot, after abandoned lot. Broken glass in boarded up doorways were the gathering places for people with nowhere else to go. Children played with whatever was lying around; hollering mothers worried about what they were picking up. The lines of poverty and racism, the systematic marginalization and neglect of (primarily) black people in the United States, resulted in the overdetermined positioning of the so-called 'inner-city ghetto.'

These lines of death ${ }^{\mathrm{i}}$ were produced through the conjunctions of policy, brutality, racism and poverty that resulted in a territorialization of this place as a site of crime, violence, drug addiction and hopelessness. But at the beginning of the 20th century, this neighbourhood was the site of summer homes, known for its fields of strawberries. It was then refashioned into a bustling heart of manufacturing, the fields were paved over, and the taste of strawberries turned to burning plastics. The depression hit. Factories began to 
close, leaving nothing in their wake but a faint rancid smell and contaminated soil. The neighbourhood transformed, riding a wave of white flight and racial tension. People rose up, spoke out and refused to suffer any longer, but in the turmoil, in their anger, they burned the neighbourhood. More suffering, but this time there was simply a feeling of abandonment, hopelessness, stagnation. The policies of the Reagan years left their effect. Lots collected garbage. And so it was that Yeh found herself in North Philadelphia.

But, it was precisely the neighbourhood's decomposition that allowed it to sprout new life, put down new roots. It was precisely because of the decay of this place that the Village of Arts and Humanities was born. City planners and social workers were nowhere to be found. Granting agencies never asked who owned the property that was eventually converted (Scher 2005). Yeh, and her team of children and adults from the neighbourhood, were never stopped and asked what they were doing when they first drew a circle in one abandoned lot, and then began to dig.

The Village of Arts and Humanities, as it stands now, is composed of twelve art parks and sculpture gardens. The meditation garden, just one of these places transformed by the Village, is enclosed by low-lying brick walls on three sides, their tops bulging, curving, playfully marking out the space. On the fourth wall, the only one that extends a full two-stories up, attached to the adjacent building, is a stunning mosaic. A tree, full of blue and white blossoms, seems to erupt in all directions, sprouting life and joy. There is a deep sense of peace to the garden, brought on by the subdued hues of sand-coloured brick, and in the centre, an unexpected circular mound. It looks inviting, a place to sit, rest, meditate, as the name of the garden indicates. Another mosaic project from the Village is 'Angel Alley'. Almost the entirety of one wall of the alley is covered with a 
mosaic of angels, black Ethiopian angels, dressed in the most fantastic and courtly dresses, keeping a benevolent watch over the passers-by. And this beauty of mosaics, carefully designed walls, poles painted and erected to mark tribute, as well as a tree farm, and various vegetable gardens, all extends over a 250-block area (Scher 2005). There is also a theatre program for youth, a comprehensive community-development project entitled 'Shared Prosperity', Narcotics Anonymous meetings, cooking clubs for young mothers, and activity all around (Miller 2005).

The Village of Arts and Humanities was not intended as a social justice project, although it was later heralded as such, with Yeh given numerous awards for her civic engagement ${ }^{\mathrm{ii}}$. The project did not gear itself towards the 'fixing' of these overwhelming social problems. It could not do this directly, was not capable of it, because its mode of production was art. Art "produces sensations, affects, intensities as its mode of addressing problems, which sometimes align with and link to concepts” (Grosz 2008: 1) but not necessarily, not directly. The collective production of art at the Village did not address the social and political problems of the neighbourhood, but created blocs of sensation, intensities that impacted nervous systems.

\section{Art as other-than-human}

If art cannot address social and political problems directly, how is it that its collective production at the Village seems to have had this effect? In order to answer this question, I start with elaborating more thoroughly a definition of art. Deleuze and Guattari define art as a bloc of sensations "that is to say a compound of percepts and affects" (Deleuze and Guattari 1994:164). Where "percepts are no longer perceptions; they are independent of a state of those who experience them. Affects are no longer 
feelings or affections; they go beyond the strength of those who undergo them.... The work of art is a being of sensation and nothing else: it exists in itself' (ibid.). In this definition of art, art is autonomous, functioning apart from, not simply its creators, but also its receivers, removing art from a mode of theorizing that focuses on its conceptual apparatus as well as from theories of reception. It is not the content of the art, nor how an individual receives it that determines its power in the world. Art in the Village exists in itself, as blocs of sensation, separate from what it represents, its beauty and magic transform the neighbourhood and the people in it through intensity.

Further, art can be thought of as a kind of frame, a framing of chaos.

Undifferentiated chaos remains in the background, outside our abilities of perception, which, if we were to access it, would overwhelm our sensory apparatus. The framing of chaos, then, is essential, as it allows something of this chaos in to emerge as the new. But in its newness, it continues to be excessive, to push against the frame, creating art. Elizabeth Grosz elaborates: "Art proper, in other words, emerges when sensation can detach itself and gain an autonomy from its creator and its perceiver, when something of the chaos from which it is drawn can breathe and have a life of its own" (Grosz 2008: 7). The Village itself exists as a kind of frame, framing the chaos of the neighbourhood, to recompose it, to become new. The materials for the art were scavenged from what was abandoned, discarded, literally taking the chaos of the surroundings and re-framing it in such a way that it generated new sensations, moving from detritus to beauty.

Art, as a framing of chaos, through its generation of the new, is the activity of life itself. The consequence of this ontology is that art no longer remains strictly the work of humans. Art is wrested, not just from the grips of a modernist paradigm of individual 
genius, but more importantly, from the exclusivity of the domination of one species. Elizabeth Grosz links this kind of artistic production to the ways in which sexual selection operates in an evolutionary framework. Art, she says, is a "fundamentally dynamic, awkward, mal-adaptation that enables the production of the frivolous, the unnecessary, the pleasing, the sensory for their own sake" (Grosz 2008: 7). In other words, the creation of excessive intensities, purely in pursuit of sensory experience, similar to that which is manifested by all kinds of creatures, can be thought of as art. For example, the elaborate mating calls and dances displayed by many kinds of birds are not necessary for survival, but do proliferate differences, and in these differences, generate life. This definition of art seems to lend itself to thinking through our relations with the world that goes beyond the 'human.' If we think of art as intensity, as the excessive products of life, then our relations with the other-than-human are necessarily expanded, and our ideas of how subjectivity and collectivity can be thought and practiced must also expand.

\section{The Village as Collective Event}

Through the creation of art, proliferating difference, the Village becomes an event: a rupture, a displacement of a pre-determined territorialization of people and place. It is the intensity produced through art that allows for a redistribution of the virtual into an event. Here an event is a "diachronic emergence, or creativity in the production of new patterns and thresholds of behavior ...The Deleuzean event re-patterns a system" (Protevi 2008: 14). This event, in the case of the Village of Arts and Humanities, re-patterns a locality. It is reorganized from a stereotypically distressed neighbourhood, into a collective. The building of art parks and sculpture gardens is not simply about reworking 
land or redesigning public space. The art pieces are blocs of sensation, separate from any utilitarian function. People's movements change, the way they carry themselves, the places they congregate. Openness and possibility begin to characterize the neighbourhood. This is fundamentally different from the re-patterning of city planning. The buildings are not torn down, with condos to replace them. Instead, the Village works to refurbish existing buildings, to create art together, to utilize the abandoned spaces as opportunities to create surprise. It is art's excessive purposelessness, through the creation of intensity and beauty that opens the possibility for new patterns to emerge between people in this place. As comments from former Managing Director Heidi Warren suggest, art enables people to move from stratified subjectivities, to ones that are more open:

And the guys in the crew were all people who had some sort of drug problems and some criminal background. ... They were known quantities. And they were mostly known as negative quantities. And that was also a very powerful thing for people to see these somewhat hoodlum, if nothing else, guys who were part of the drug culture doing something productive and creating beauty and getting rid of the trash and working hard... It was great for the guys. It was great for the neighbourhood. They didn't all make it, you know. They did that project and some fell back into the world they were involved in, but for that period of time, it was magic. (Miller 2005: 64, emphasis added)

People, formerly characterized and understood as 'hoodlums' and 'known quantities,' become something else, even if temporarily. While the excessiveness of art production does not imply a pre-determined outcome, possibilities for emergence and difference are opened up.

The Village, as an event, opens up the possibility for collectivity. Rather than simply conceiving of the collective as human subjects, agents of a work, we need, I think, to expand this notion to fully understand how it is that collectives function. An art 
collective must account for the specific autonomy of art, and so the collective becomes an aggregate of humans and other-than-humans. If we think of the collective in this way, then the artist is decentered. She still acts as a vector, or locator, the collector of materials, but the work is a kind of being in itself. The possibilities opened up by the Village were not just created by Lily Yeh. Nor were they only created by Lily Yeh and the many members of the community, who became her accomplices (sometimes, as in the case of James 'Big Man’ Maxton, for nearly 20 years). The openness produced by the Village was created by the aggregate of non-human and human actors: by the potential of the derelict neighbourhood, by community members, by Yeh, and by the art itself. Art in the Village is an aggregate of the actors and forces, actualized through the asymmetric relations of participants that expand beyond the powers of each.

These aggregates are turned into collectives because of emotional attachment. But, as Sara Ahmed explains, “...the role of emotion in aligning individual and collective, [is not straight-forward,] such emotions do not come from either the inside (psyche) or the outside (collective), but allow for the very surfacing of bodies and collectives" (Ahmed 2005: 100). The relations that solidify affects into emotions are what allow for a distinction between oneself and the world, allow for an enunciation of the collective as being with others, and for the distinction of subjects from that collective. A collective does not mean that stratifications of power are erased, rather that structures between people fall in and out of these stratifications, where lateral movement becomes a possibility ${ }^{\text {iii }}$. Similarly, it is through an oscillation of inside and outside that non-humans create, and become a part of, a collective. The artworks in the Village "create gaps by inserting alternative realities into the flow of everyday events - the story in the 
conversation, the mural on the wall, the sculpture in the park. We are drawn out of the quotidian time and space into an alternate one, the space between" (Miller 2005: 72). This space between, as an oscillation between collective and subject, between bodies and place, is what allows for different possibilities of collectivity. The collective emerges out of the interaction between people and place, involving the transformation of subjective relations. Formulating this collective through artistic production, it seems, heightens intensity, opens onto new thresholds, new percepts and affects that can redistribute the system and the relations between people.

To return to the meditation garden, it is the square itself, excessive of its function as a gathering place, decidedly not addressing drug addiction, poverty, or the myriad of other problems of the previously blighted neighbourhood, that repatterns the locality. It spills over its borders, drawing people in and around, as a collective. It is the excessiveness of art, its " useless production — production for its own sake, production for the sake of profusion and differentiation"- that emerges as differences, gaps that become the nestling place of humans and birds (Grosz 2008: 9). Perhaps the connections between nature and art should be taken more seriously, reproducing life's propagation of differences. This would involve the multiplications of intensity and sensation proliferating around our cities, creating useless differences that put kinks in processes of territorialization. What emerges, in recognizing art's autonomous sensation, is an ability to transform our notions of collectivity, and urban systems. 


\section{Works Cited}

Ahmed, Sara. 2005. "The Skin of the Community: Affect and Boundary Formation." Revolt, Affect, Collectivity: The Unstable Boundaries of Kristeva's Polis. Edited by T. Chanter and E. Ziarek. New York: SUNY Press: 95-112.

Deleuze, Gilles and Felix Guattari. 1987. A Thousand Plateaus. Trans. Brian Massumi. Minneapolis: University of Minnesota Press.

Deleuze, Gilles and Felix Guattari. 1994. What is Philosophy? Trans. Hugh Tomlinson and Graham Burchell. New York: Columbia University Press.

Grosz, Elizabeth. 2008. Chaos, Territory, Art: Deleuze and the framing of the earth. New York:Columbia University Press.

Kester, Grant. 2004. Conversation Pieces: Community and Communication in Modern Art. Berkeley: University of California Press.

Kwon, Miwon. 2002. One Place After Another: Site-specific Art and Locational Identity. Cambridge, Mass.: MIT Press.

Leggiere, Phil. 2000. "Lily Yeh's Art of Transformation." The Pennsylvania Gazette. July/August. http://www.upenn.edu/gazette/0700/leggiere.html [accessed Nov. 9, 2009]

Miller, Rosina. 2005. Performing the Urban Village: Art, Place-making and Cultural Politics in North Central Philadelphia. Philadelphia: University of Pennsylvania Press. Scher, Abbey. 2005 “Art in the Village.” YES Magazine. http://www.yesmagazine.org/article.asp?ID=1263 [accessed 30 March, 2009]

Protevi, John. 2008. Political Physiology: Imbrications of the Social and the Somatic. Unpublished Manuscript. 
${ }^{i}$ Deleuze and Guattari use this term to describe the danger of the passion of abolition: "the line of flight crossing the wall, getting out of the black holes, but instead of connecting with other lines and each time augmenting its valence, turning to destruction, abolition pure and simple, the passion of abolition. Like Kleist's line of flight, and the strange war he wages; like suicide, double suicide, a way out that turns the line of flight into a line of death" (Deleuze and Guattari 1987: 229).

ii Amongst local achievements, Yeh and the Village were also awarded the prestigious Leadership for a Changing World in 2003.

iii See Miwon Kwon (2002) especially chapters 4 and 5; and Grant Kester (2004), chapter 5 for interesting and complex accounts of the problematic nature of 'community-engaged art' and hierarchicalized power structures between artists and communities. I wish to acknowledge a great debt to these authors in thinking through these complex, stratified relations, but my focus here is on trying to think beyond the individual power of discrete subjects without dismissing these realities. 